Integritas 4.3 (Fall 2014), pp. 31-35.

doi: 10.6017/integritas.v4i3p31

\title{
Response to Amata Miller
}

\section{Paul Mariani}

I should have known when I signed on to Boston College and then a project like the Boston College Roundtable focusing on advancing the mission of Catholic higher education that at some point I would find an elephant crashing around the room andas Flannery O'Connor famously said of Christ - throwing everything off balance.

What I didn't see was that Sister Amata Miller would be the one who brought the necessary raging presence through the hall doors and into this room. In fact, the elephant is breathing heavily down my neck now, as I stand before you in the closing sessions of our Roundtable discussions.

When I addressed you two years ago on the subject of the great Catholic literary tradition and spoke of Dante, John Donne, George Herbert, Milton, Fr. Hopkins, Chesterton, T.S. Eliot, Merton, O’Connor, Ron Hansen, and Alice McDermott among others, and then spoke of the problem of evil in a literary context, the purgatorial journey, and those glitter-go shards of grasshopper flights into the transcendent we may be blessed with, ${ }^{\mathrm{I}}$ I had not taken into sufficient account how uncomfortable I find it to have to look daily into the broken face of Christ as it manifests itself in the poor, the trapped, the sick, the hungry, and the homeless. Having myself been born into a world that inhabited the lower end of the economic food chain, it was natural to want to escape that. By grace of faith, I had the luck of being born into a post-Depression America

1 Paul Mariani, "Charism and the Literary Imagination," Integritas 1.2 (Spring 2013), 1-19.

Paul Mariani is the University Professor of English and holds a chair position in the English department at Boston College. He has published over 200 essays and reviews and is the author of 17 books, including six biographies, seven volumes of poetry, and a spiritual memoir. His awards include fellowships from the Guggenheim Foundation, the National Endowment for the Arts, and two fellowships from the National Endowment for the Humanities. He has lectured and read from his own work throughout the United States as well as in Canada and Europe. His poems, which have been widely anthologized, have appeared in: Image; Poetry; America; Doubletake; The Kenyon Review; The Agni Review; New England Review; Crazyhorse; Southern Quarterly; The Hudson Review; Sundog; Tri-Quarterly; and The New Criterion. 
where it was possible for millions to make a good living and-given an education-to find a way out of the worst aspects of marginal poverty.

How much more pleasant, really, to be able to dwell in Dante's Circle of Philosophers, where one could discourse on beauty and truth and the possible existence of God, or muse endlessly with Li Po, Proust, Rilke, and Wallace Stevens on Plato's worlds of shadow and light over an exquisite glass or three of Chardonnay.

And then to have all of that upturned as one enters a subway station somewhere in Brooklyn and-like that young Jesuit priest in the I973 film The Exorcist-to find some bum, some homeless person lying against one of the steel support columns in his own stale urine, shaming you into handing over whatever spare change-make that a buck, pal-you have. Or St. Francis, confronting and then embracing a full-blown leper on the outskirts of Assisi. Or Nathanael Hawthorne, walking down the corridors of a British orphanage in Liverpool during his time as U.S. representative in the mid-I850s and seeing a little boy, his nose running, beseeching him with liquid eyes to pick him up and embrace him, if only for a moment.

Nathanael Hawthorne: father of Rose Hawthorne, who would go on to become the founder of an order of Sisters whose special charism was to care for the cancer-ridden. Or Dr. William Carlos Williams, on a house call to a poor old widow living alone, examining her and making her comfortable in the sharp winter cold, and then walking down into the basement, taking off his jacket and rolling up his sleeves, and getting a fire going in the coal furnace. For what good would it have been, he said, to merely wish her well and leave her to the cold before moving to his next house call?

Amata Miller, of the Sisters, Servants of the Immaculate Heart of Mary, professor of economics with a doctorate from Berkeley, and director of the Myser Initiative on Catholic Identity at St. Catherine University, has spent most of her life thinking about, championing, and working with the poor in one capacity or another, always as an advocate for our neediest sisters and brothers. For the common wealth, she has insisted now for over half a century, must be distributed in a just and equitable manner.

Helping those she has taught over the years become agents of social justice has been part of her work. And Michigan Supreme Court Justice Maura Corrigan, her student back in the volatile I96os, has said that Sister Amata had the most profound influence on her of any teacher in her life. "She opened worlds of knowledge to us and offered a firm commitment to scholarship and rationality in this often chaotic world." This often chaotic world....

And when Sister Amata became the financial vice president of her religious congregation, a post she held for a dozen years, she continued to speak out for economic justice. She has advocated for socially responsible investing and has worked for equity compensation for women religious. For six years she served as an economic analyst for the National Catholic Social Justice Lobby in Washington, D.C., so I have to believe she knows whereof she speaks when it comes to economics.

Because I'm a slow learner, I had to read and reread the talk she just delivered six 
times before I began to understand the complexities of her arguments for distributive economic justice and an end to obscene poverty in a period of unprecedented affluence. In doing so, she outlined for us the roots of economic parity and social responsibility from those Jewish agricultural societies we find in Exodus, Deuteronomy, Leviticus, Isaiah and Amos.

She has reminded us of God's determination to free his people from slavery in Egypt when he sent Moses to confront the pharaoh himself. She has reminded us of the Jubilee, which called for the return of all lands to their original owners without compensation every 50 years, and of sabbaticals, by which slaves and debtors and even the soil might be freed every seven years. She spoke of interest-free loans for the poor, of the radical economics Jesus practiced, where wealth was shared and where we were responsible for the care and well-being of one another.

She spoke too of the rise of women religious orders caring for orphans, schools, and hospitals for the poor in the I50 years predating Pope Leo XIII's groundbreaking encyclical Rerum Novarum of I89I, which would address the issues of economic justice, social equity, and responsibility, and of the encyclicals and papal letters which have followed down to our own day in the addresses of Pius XII, John XXIII, John Paul, Benedict, and now Francis. She spoke of Liberation Theology in addressing the realities of destitution and oppression in Latin America, and of the terrible human cost of advocating for justice against entrenched power.

She has called upon Modern Catholic Social Teaching to guide us in bringing a moral dimension into public discussions of social issues. In short, she has asked us what the economy, a machine which should hum along quietly to take care of the needs of all of us, does when it malfunctions by keeping the majority of human beings not only from flourishing as they should, but of stripping us of our inherent dignity while money pools lifelessly like blood oil around the Gucci shoes of a relative handful.

And then, to bring her talk home to roost, she has reminded us that we who teach and work at Catholic colleges and universities must play a key role in fostering the necessary political will in our students by making them more fully aware of our shared social responsibility, because-yes-there is much that needs to be done to repair the global economic injustice of our times. True, since the collapse of Russian communism, there has been real progress toward righting some of these wrongs, though there have also been some serious setbacks in the last five years.

She has reminded us too of the mission statements of our Catholic universities and colleges and of our promise to educate the whole person through the study of the liberal arts-theology, philosophy, history, literature-all rooted in the Catholic intellectual tradition. But she also reminds us that too often the economic dimension of life has been ignored as something to be taught only in business classes, so that we, uninformed about the true economic dimensions of reality, too often seek instead dreamy myths which tend to evaporate in due course, leaving us all the worse for it. Rightfully so, she speaks of our contact with the poor and marginalized, including those we meet or pass 
by every day of our lives, giving to money and wealth "a false dominance" by accepting the inequities and exclusions that go with a rigged market economy. Our rich heritage of Catholic social teaching, she reminds us, must be integrated into our general education core, and it is our responsibility as teachers to make clear to our students what their rights and responsibilities as human beings are, and do this by our actions rather than by merely using words.

All of this we need to do in our classes, our residence halls, and in immersion trips here and abroad. I think of my own Jesuit son working to feed the hungry in Mexico, or working with L'Arche communities in Seattle, or working with the Chinese population in San Jose. Or my wife, Eileen, working with the poor in western Massachusetts or in the backwoods of Kentucky. Or our son John, who worked with Mexican street gangs in Tucson as part of his assignment with the Jesuit Volunteer Corps, a year which determined that he would work with the too-often neglected schoolchildren of Manchester, Connecticut. Or our son Mark, who works with a large number of Korean and Mexican boys in grades six through nine and who-in spite of coming from wealth-are sent to schools far from their homes for months at a time and who crave parental guidance and personal attention. And I think, when I see such examples: if I could only hang on to the hem of their coats, I too might make it through the gates someday.

Speaking of L'Arche, here are some lines from a poem by the founder of that community, Jean Vanier, which speak to the present occasion: the cry of the oppressed and the lonely disturbs,

\author{
creates fear, \\ provokes rejection. \\ But if they are listened to, \\ they can also awaken the hearts \\ of the powerful and the wise, \\ calling them to change, \\ to conversion.... \\ As the powerful listen to the cry of love \\ surging up gently from the oppressed and the powerless, \\ they can begin to accept and love \\ the vulnerable child within themselves.
}

The cry of the poor, heard by Christ and Father Francis and Sister Amata-calling out to the world to feed Christ's sheep if you would truly love Him. Then multiply such instances, such Christ-like instances, by a hundred, a thousandfold, a millionfold, and one begins to see how real change could be had in our world.

You do what you can, remembering that one feeds the hungry not only with bread, but with words and by acts of attention to each person one teaches, if that is the charism one has been given. One serves the hungry not only by offering them a fish, but by 
teaching them how to fish so that they can in turn feed themselves and others. Or, if you are truly fortunate, you offer them the bread of Christ on a Sunday morning in an old mill town. And — as they receive the precious bread one by one by one-the young, the teenagers, the middle-aged, the elderly, you feel a joy you cannot contain, until you are fighting back tears as the hungry are fed, and you too are fed by their presence. And you understand then that it is as Christ said, a sense of oneness beyond language, all of it wrapped in a shawl of light because we who are poor have been so richly fed. 
